\title{
Metastatic Malignant Digestive System Neoplasm
}

National Cancer Institute

\section{Source}

National Cancer Institute. Metastatic Malignant Digestive System Neoplasm. NCI

Thesaurus. Code C162255.

A malignant neoplasm that arises in the digestive system and has spread from its original site of growth to other anatomic sites. 